\title{
SBI, Jumlah Uang Beredar, dan Ekspor terhadap Inflasi dan Cadangan Devisa di Indonesia
}

\author{
Firmansyah \\ Sekolah Tinggi Ilmu Ekonomi (STIE) Mahaputra Riau \\ e-mail: firmansyahhimansyah@yahoo.ac.id \\ Safrizal \\ Fakultas Ekonomi Universitas Samudra \\ e-mail:safrizal@unsam.ac.id
}

\begin{abstract}
Abstrak
Tujuan penelitian ini adalah menganalisis pengaruh SBI, jumlah uang beredar dan ekspor terhadap inflasi dan cadangan devisa di Indonesia. Secara terperinci, permasalahan yang dibahas adalah bagaimana: (a) pengaruh SBI terhadap inflasi di Indonesia; (b) pengaruh jumlah uang beredar terhadap inflasi di Indonesia; (c) pengaruh ekspor terhadap inflasi di Indonesia; dan, (d) pengaruh inflasi terhadap cadangan devisa di Indonesia. Metode analisis data menggunakan regresi linier berganda, dengan uji hipotesis menggunakan uji t dan uji F. Hasil penelitian yang diperoleh menunjukkan bahwa SBI, jumlah uang beredar, dan ekspor memiliki pengaruh yang tidak signifikan terhadap inflasi. Hasil lainnya menyatakan bahwa inflasi berpengaruh terhadap cadangan devisa.
\end{abstract}

Kata kunci: SBI, jumlah uang beredar, ekspor, inflasi, cadangan devisa .

\section{PENDAHULUAN}

Fenomena ekonomi di dunia baik fenomena baik atau fenomena buruknya, pada kondisi sekarang ini fenomena yang terjadi seperti perkembangan inflasi yang setiap negara memiliki permasalahan masingmasing yang tergantung pada kondisi negara tersebut.

Dalam kondisi pelaksanaannya, inflasi memiliki atau menghasilkan dampak yang berpositif maupun dampak yang negatif. Aapabila inflasi yang dihasilkan Negara tersebut memiliki inflasi yang rendah maka para investor akan lebih mungkin berminat untuk berinvestasi ke negara tersebut; begitu juga sebaliknya.

Ada beberapa faktor yang berdampak atau dapat berpengaruh terhadap inflasi, seperti suku bunga, jumlah uang beredar maupun ekspor. Menurut Krisnaldy (2017), inflasi di Indonesia dapat dipengaruhi oleh beberapa faktor, seperti jumlah uang beredar (JUB). Menurut kaum moneteris, jumlah uang beredar adalah faktor utama penyebab inflasi. Apalagi persentase peredaran uang kartal lebih kecil daripada persentase jumlah uang giral, sehingga berdampak terhadap semakin sulitnya proses pengendalian jumlah uang beredar, juga semakin meluasnya moneterisasi dalam kegiatan perekonomian. Faktor lainnya yang mengakibatkan terjadinya inflasi adalah Produk Domestik Bruto (PDB), dimana pendapatan masyarakat berpengaruh terhadap tingkat inflasi. Apabila pendapatan masyarakat turun, maka inflasi akan meningkat.

Tujuan penelitian yang didasarkan pada latar belakang adalah untuk mengetahui: (a) pengaruh suku bunga bank Indonesia berpengaruh terhadap inflasi di Indonesia; (b) pengaruh jumlah uang beredar terhadap inflasi di Indonesia; (c) pengaruh ekspor terhadap inflasi di Indonesia; dan, (d) pengaruh inflasi terhadap cadangan devisa di Indonesia. 


\section{Kajian Pustaka dan Pengembangan Hipotesis}

Nilai uang ditentukan oleh supply dan demand terhadap uang. Jumlah uang beredar ditentukan oleh Bank Sentral, sementara jumlah uang yang diminta (money demand) ditentukan oleh beberapa faktor, antara lain tingkat harga rata-rata dalam perekonomian. Jumlah uang yang diminta oleh masyarakat untuk melakukan transaksi bergantung pada tingkat harga barang dan jasa yang tersedia. Semakin tinggi tingkat harga, semakin besar jumlah uang yang diminta (Perlambang, 2010).

Peningkatan harga tersebut kemudian mendorong naiknya jumlah dari uang yang diminta masyarakat. Pada akhirnya, perekonomian akan mencapai equilibrium baru, saat jumlah uang yang diminta kembali seimbang dengan jumlah uang yang diedarkan. Penjelasan yang menggambarkan bagaimana tingkat harga ditentukan dan berubah seiring dengan perubahan jumlah uang beredar disebut Teori Kuantitas Uang (Quantity Theory Of Money) (Perlambang, 2010).

Beberapa penelitian sebelumnya yang terkait pada penelitian ini dan digunakan sebagai pedoman atau acuan pada bahasan dalam penelitian ini diuraikan sebagai berikut.

Agustina dan Reny (2014) melakukan penelitian tentang pengaruh ekspor, impor, nilai tukar rupiah, dan tingkat inflasi terhadap cadangan devisa Indonesia. Hasil penelitian menyatakan bahwa ekspor, impor, nilai tukar rupiah dan tingkat inflasi berpengaruh atas cadangan devisa Indonesia. Namun secara parsial, ekspor berpengaruh positif dan signifikan atas cadangan devisa Indonesia; nilai tukar rupiah berpengaruh negatif dan signifikan terhadap cadangan devisa Indonesia; sedangkan impor dan nilai tukar rupiah tidak berpengaruh terhadap cadangan devisa Indonesia.

Adiyandya (2017) melakukan penelitian tentang pengaruh inflasi, kurs dollar amerika, suku bunga kredit dan utang luar negeri terhadap cadangan devisa Indonesia periode tahun 1996-2015. Hasil penelitiannya menyatakan bahwa inflasi, kurs dollar amerika, suku bunga kredit dan utang luar negeri secara simultan berpengaruh signifikan terhadap cadangan devisa Indonesia tahun 1996-2015. Secara parsial, penelitian ini menemukan bahwa inflasi tidak berpengaruh terhadap terhadap cadangan devisa Indonesia; Inflasi tidak berpengaruh terhadap terhadap cadangan devisa Indonesia; suku bunga kredit berpengaruh negatif dan signifikan terhadap cadangan devisa Indonesia; serta, utang luar negeri berpengaruh positif dan signifikan terhadap cadangan devisa Indonesia selama periode penelitian, yaitu tahun 1996-2015.

Krisnaldy (2017) melakukan penelitian tentang pengaruh jumlah uang beredar, produk domestik bruto, kurs dan tingkat bunga terhadap inflasi di Indonesia dengan pendekatan Error Corection Model (ECM). Hasil penelitian menunjukkan pertumbuhan jumlah uang beredar, pertumbuhan produk domestik bruto dan tingkat bunga tidak berpengaruh signifikan terhadap perubahan tingkat inflasi dalam jangka pendek. Hanya variabel pertumbuhan kurs terhadap USD yang berpengaruh signifikan pada perubahan tingkat Inflasi dalam jangka pendek.

Larasati dan Amri (2017) melakukan penelitian mengenai pengaruh tingkat suku bunga sertifikat Bank Indonesia dan nilai tukar terhadap inflasi di Indonesia. Hasil penelitian menunjukkan bahwa suku bunga SBI mempengaruhi inflasi (INF) secara positif dan signifikan; sedangkan nilai tukar berpengaruh secara negatif dan signifikan terhadap Inflasi di Indonesia.

Perlambang (2010) melakukan penelitian yang mengnalisis pengaruh jumlah uang beredar, suku bunga SBI, nilai tukar terhadap tingkat inflasi. Hasil penelitian ini menyatakan bahwa jumlah uang beredar tidak berpengaruh signifikan terhadap inflasi; SBI memiliki pengaruh signifikan dan positif terhadap inflasi; dan nilai tukar (Rp/USD) tidak berpengaruh signifikan terhadap inflasi.

Putra dan Indrajaya (2013) melakukan mengenai pengaruh tingkat inflasi, utang luar negeri dan suku bunga kredit terhadap cadangan devisa Indonesia tahun 1996-2011. Hasil analisis data menunjukkan bahwa secara serempak, tingkat inflasi, utang luar negeri dan suku bunga kredit berpengaruh signifikan 
terhadap cadangan devisa Indonesia. Nilai koefisien determinasi $\left(\mathrm{R}^{2}\right)$ sebesar 0,964 berarti 96,4 persen variasi (naik turunnya) cadangan devisa Indonesia tahun 1996-2011 dipengaruhi oleh variasi (naik turunnya) tingkat inflasi, utang luar negeri dan suku bunga kredit; sedangkan sisanya sebesar 3,6 persen dipengaruhi oleh variabel lain yang tidak dimasukkan dalam model penelitian. Secara parsial, tingkat inflasi tidak memiliki pengaruh, utang luar negeri berpengaruh positif dan siginifikan, dan suku bunga kredit berpengaruh negatif dan signifikan, terhadap cadangan devisa Indonesia tahun 1996-2011.

\section{SBI dan Jumlah Uang Beredar terhadap Inflasi}

Menurut Krisnaldy (2017), inflasi di Indonesia dapat dipengaruhi oleh beberapa faktor, seperti jumlah uang beredar. Menurut kaum moneteris, jumlah uang beredar adalah faktor utama penyebab inflasi. Apalagi persentase peredaran uang kartal lebih kecil daripada persentase jumlah uang giral sehingga berdampak terhadap semakin sulitnya proses pengendalian jumlah uang beredar, selain juga semakin meluasnya moneterisasi dalam kegiatan perekonomian. Faktor lainnya yang mengakibatkan terjadinya inflasi adalah Produk Domestik Bruto (PDB), dimana pendapatan masyarakat berpengaruh terhadap tingkat inflasi. Apabila pendapatan masyarakat turun, maka inflasi akan meningkat.

\section{Ekspor terhadap Inflasi}

Ekspor juga dipengaruhi oleh tingkat inflasi. Seperti diungkapkan oleh Silviana
(2016) bahwa inflasi merupakan proses kenaikan harga-harga umum dari barangbarang secara terus menerus selama periode tertentu. Tingkat inflasi melemahkan neraca perdagangan. Argumen ini disebabkan karena inflasi akan mendorong pelemahan daya saing, dan akhirnya menyebabkan penurunan ekspor (Ansahari dkk., 2017).

\section{Inflasi terhadap Cadangan Devisa}

Beberapa faktor yang mempengaruhi cadangan devisa, yaitu ekspor, impor, nilai tukar rupiah, dan tingkat inflasi. Hubungan ekspor terhadap cadangan devisa adalah dalam melakukan kegiatan ekspor, dimana suatu negara akan memperoleh berupa nilai sejumlah uang dalam valuta asing atau biasa disebut dengan istilah devisa, yang juga merupakan salah satu sumber pemasukan negara. Sehingga apabila tingkat ekspor mengalami penurunan, maka akan diikuti dengan ikut menurunnya cadangan devisa yang dimiliki (Agustina \& Reny, 2014).

\section{Hipotesis}

Berdasarkan hasil penelitian terdahulu serta kajian teoritis, dapat dikemukakan kerangka pemikiran seperti pada Gambar 1 . Selanjutnya, berlandaskan kerangka itu maka dimunculkan empat hipotesis yang di uji dalam penelitian ini, yaitu: (1) suku bunga Bank Indonesia (SBI) berpengaruh signifikan terhadap inflasi di Indonesia; (2) jumlah uang beredar berpengaruh signifikan terhadap inflasi di Indonesia; (3) ekspor berpengaruh signifikan terhadap inflasi di Indonesia; dan, (4) inflasi berpengaruh signifikan terhadap cadangan devisa di Indonesia.

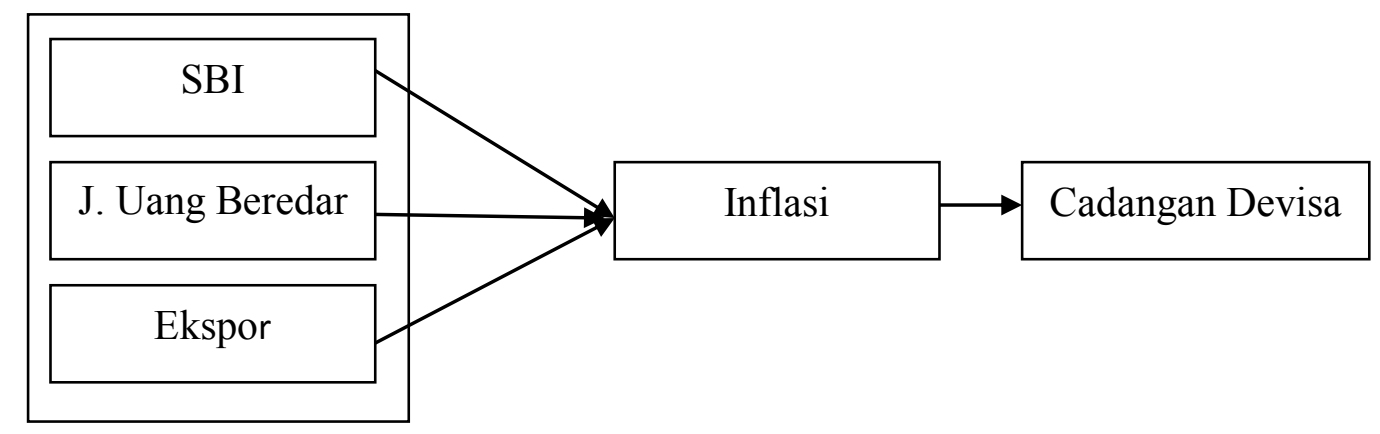

Sumber: Diolah peneliti, tahun 2018.

Gambar 1. Kerangka Pemikiran 


\section{METODE PENELITIAN}

\section{Lokasi dan Objek Penelitian}

Lokasi penelitian ini dilakukan pada seluruh wilayah yang ada di Indonesia, dengan data sekunder yang telah publikasi. Data sekunder yang dimaksud adalah SBI (Suku Bunga Bank Indonesia), jumlah uang beredar, ekspor, inflasi dan cadangan devisa. Objek penelitian yang dilakukan yaitu pengaruh SBI, jumlah uang beredar, dan ekspor terhadap inflasi dan cadangan devisa.

\section{Metode Pengumpulan dan Analisis Data}

Metode pengumpulan data pada konsep penelitian ini yaitu dengan mengamati, dan mempelajari uraian-uraian teori yang berasal baik dari publikasi ilmiah, Bank Indonesia, Badan Pusat Statistik dan lain sebagainya yang dapat mendukung konsep penelitian ini.

Proses analisis data pada penelitian ini menggunakan metode regresi berganda. Pada metode ini juga dilakukan uji asumsi klasik yang terdiri dari uji normalitas, uji heterokedastisitas, uji multikolinieritas dan uji autokorelasi.

\section{HASIL ANALISIS}

\section{Uji Asumsi Klasik}

Uji asumsi klasik harus dapat dilakukan pada setiap model regresi. Pada umumnya, uji asumsi klasik yang harus dilakukan pada uji regresi berganda. Uji asumsi klasik pada model regresi ini terdiri dari uji normalitas, uji heterokedastisitas, uji multikolinieritas, dan uji autokorelasi.

\section{Uji Normalitas}

Uji normalitas merupakan uji yang bertujuan untuk dapat diketahui suatu data dapat terdistribusi normal atau tidaknya. Pada uji normalitas data, dapat diketahui dengan menggunakan grafik histogram, grafik Normal P-Plot dan Kolmogrov-Smirnov. Hasil uji normalitas menggunakan grafik histogram ditunjukkan pada Gambar 2.

Berdasarkan grafik histogram pada Gambar 2 terlihat pola yang telah mengikuti kurva normal. Walaupun ada beberapa data yang tampak terlihat adanya outlier, namun secara garis besar data terdistribusi data mengikuti kurva normal. Dengan demikian, dapat disimpulkan bahwa data dalam model penelitian ini telah berdistribusi normal.

Selanjutnya, pada Gambar 3 menunjukkan grafik Normal P-Plot. Pada gambar tersebut terlihat Plot pada uji normalitas memiliki titik-titik yang mendekati dan mengikuti garis diagonal. Dengan demikian, berdasarkan grafik Normal P-Plot, model regresi penelitian ini juga dinyatakan terdistribusi normal.

\section{Histogram}

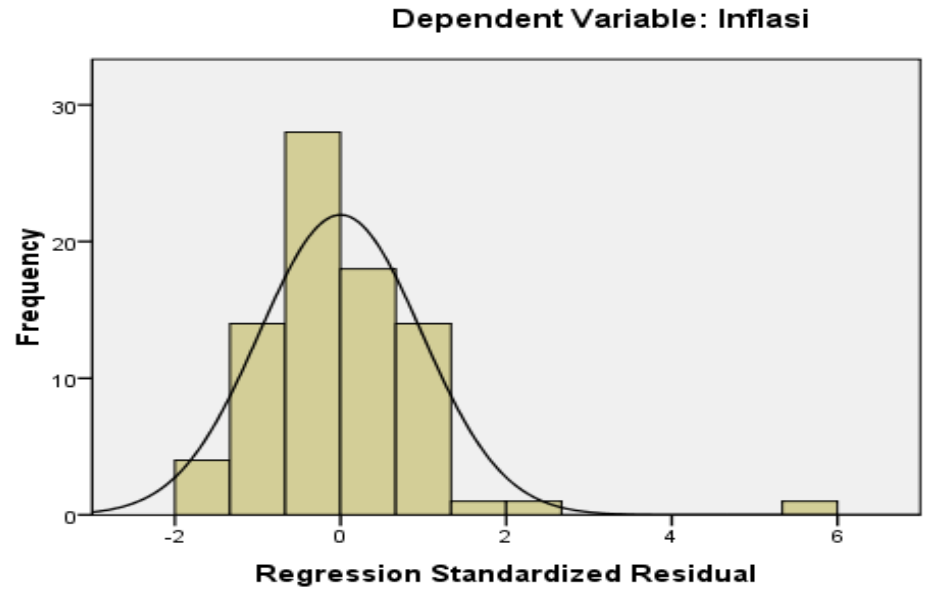

Sumber: Diolah peneliti, tahun 2018.

Gambar 2. Hasil Grafik Histogram 

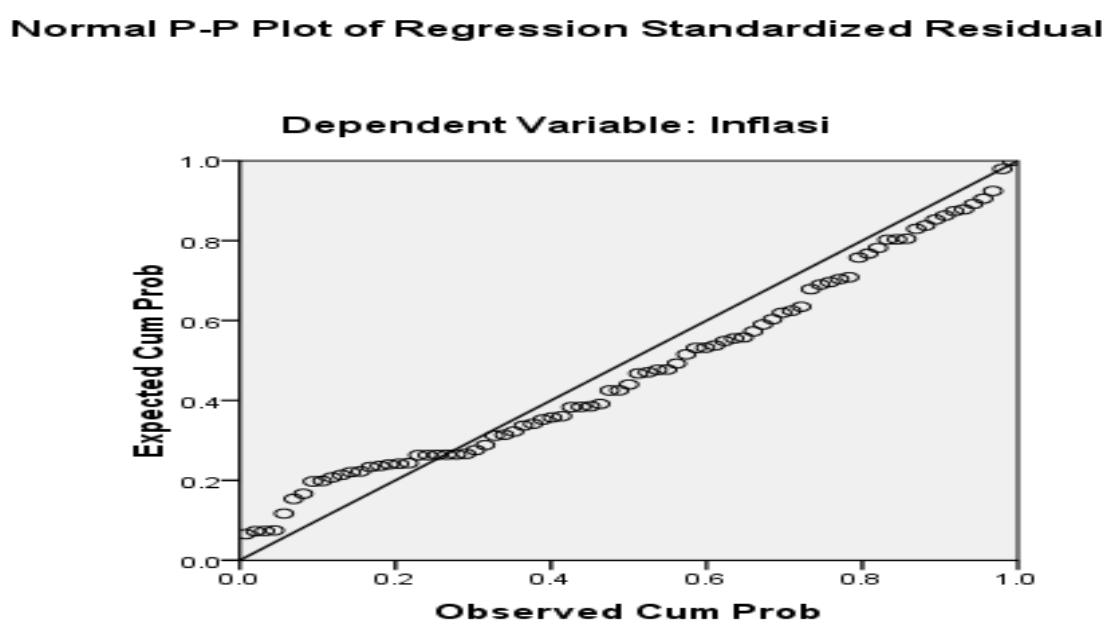

Sumber: Diolah peneliti, tahun 2018.

Gambar 2. Hasil Grafik Normal P-Plot

Tabel 2. Hasil Kolmogorov-Smirnov

\begin{tabular}{llr}
\hline & & \multicolumn{2}{c}{$\begin{array}{c}\text { Unstandardized } \\
\text { Residual }\end{array}$} \\
\hline $\mathrm{N}$ & & 38 \\
\hline Normal Parameters $^{\mathrm{a}}$ & Mean & 84 \\
& Std. Deviation & .0000000 \\
\hline Most Extreme Differences & Absolute & .50683287 \\
& Positive & .107 \\
& Negative & .095 \\
\hline Kolmogorov-Smirnov Z & & -.107 \\
Asymp. Sig. (2-tailed) & & .984 \\
\hline
\end{tabular}

${ }^{a}$ Test distribution is Normal

Sumber: Data sekunder (diolah), tahun 2018.

Tabel 2 menyatakan hasil uji normalitas menggunakan Kolgomorov-Smirnov. Pada tabel tersebut terlihat hasil KolmogrovSmirnov memiliki nilai absolut sebesar 0,107. Jika dibandingkan dengan nilai Tabel Kolmogrov-Smirnov sebesar 0,175 maka diperoleh bahwa hasil statistik $0,107<0,175$ yang berarti hasil itu menunjukkan bahwa data berdistribusi normal. Hasil ini didukung dengan adanya nilai Asymp. Sig (2-tailed) sebesar 0,288 yang mana jika juga dibandingkan dengan nilai $\alpha(0,05)$ maka diperoleh $0,288>0,05$ yang berarti model regresi dalam penelitian ini menghasilkan distribusi normal.

\section{Uji Heterokedastisitas}

Uji heterokedastisitas bertujuan untuk mengetahui apakah terjadi ketidaksamaan varians residual. Pada uji asumsi ini, diharapkan sebaiknya model regresi tidak mengalami residual antar pengamatan. Berdasarkan gambar scaterplot pada Gambar 3 dapat diketahui titik -titik yang menyebar diatas dan dibawah garis 0 , dengan tidak membentuk pola yang tertentu, yang berarti tidak terjadi heterokedastisitas pada model. 


\section{Scatterplot}

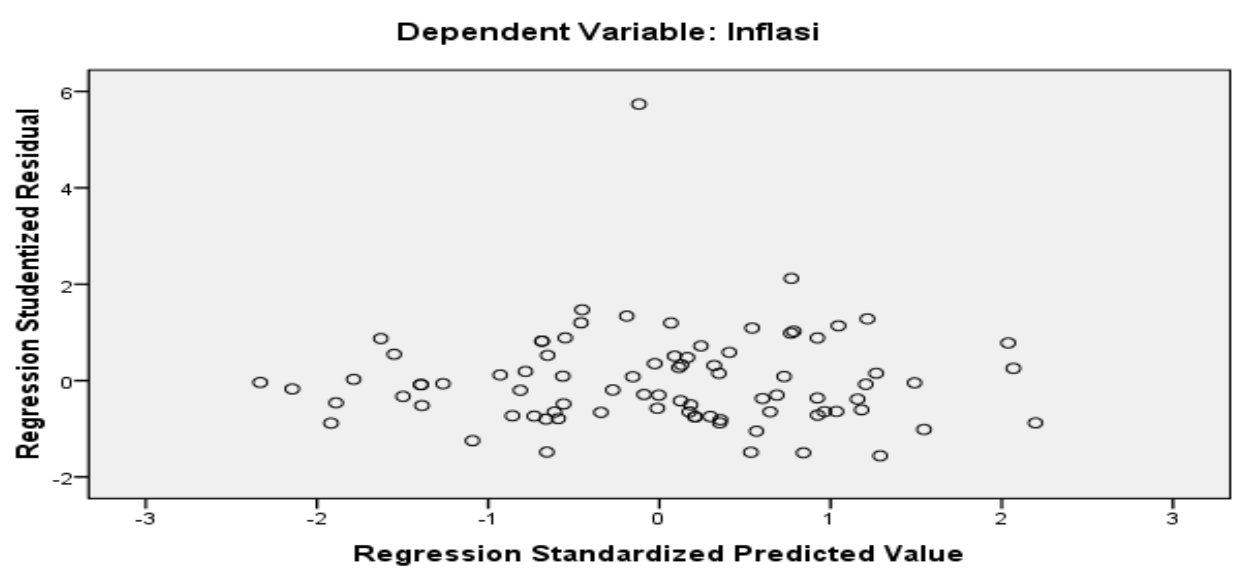

Sumber: Diolah peneliti, tahun 2018.

Gambar 3. Hasil Grafik Scatterplot

Tabel 3. Hasil Uji Heterokedastisitas

\begin{tabular}{llrr}
\hline Model & & $\mathrm{t}$ & \multicolumn{2}{c}{ Sig. } \\
\hline 1 & (Constant) & -.059 & .953 \\
& SBI & .631 & .530 \\
& Jumlah Uang Beredar & -.238 & .812 \\
& Ekspor & .598 & .551 \\
\hline
\end{tabular}

Sumber: Data sekunder (diolah), tahun 2018.

Tabel 4. Hasil Uji Multikolinieritas

\begin{tabular}{llcc}
\hline \multirow{2}{*}{ Model } & & \multicolumn{2}{c}{ Collinearity Statistics } \\
\cline { 3 - 4 } 1 & (Constant) & Tolerance & VIF \\
& SBI & .738 & 1.356 \\
& Jumlah Uang Beredar & .350 & 2.854 \\
& Ekspor & .399 & 2.504 \\
\hline
\end{tabular}

Sumber: Data sekunder (diolah), tahun 2018.

Berdasarkan hasil uji heterokedastisitas yang dideteksi dengan menggunakan uji Glejser yang ditunjukkan dalam Tabel 3, diperoleh SBI menghasilkan nilai signifikansi sebesar 0,530; jumlah uang beredar menghasilkan nilai signifikansi sebesar 0,812 ; dan, ekspor memperoleh nilai signifikansi sebesar 0,551 . Nilai-nilai signifikansi tersebut berada di atas $\alpha(0,05)$. Dengan demikian dapat disimpulkan bahwa tidak terjadi kondisi heterokedastisitas dalam model penelitian.

\section{Uji Multikolinieritas.}

Uji multikolinieritas bertujuan untuk mengetahui apakah ada terjadinya korelasi antar variabel bebas. Pada pengujian ini 
diharapkan model sebaiknya tidak mengalami adanya multikolinieritas. Pada pengambilan keputusan uji multikolinieritas, digunakan kriteria apabila nilai dari Tolerance $>0,1$ dan VIF $<10$ maka dinyatakan tidak terjadi adanya multikolinieritas; dan begitu juga sebaliknya.

Berdasarkan Tabel 4 diperoleh hasil uji multikolinieritas bahwa nilai Tolerance untuk variabel-variabel SBI, jumlah uang beredar, dan ekspor, adalah di atas 0,1 dan nilai VIF dibawah 10. Dengan demikian, hasil uji menunjukkan tidak terdeteksi adanya multikolinieritas pada model penelitian ini.

\section{Uji Autokorelasi}

Pelaksanaan uji autokorelasi bertujuan untuk dapat mengetahui apakah terjadinya residual yang didasarkan pada data antar waktu maupun antar perusahaan. Kondisi autokorelasi dapat diketahui dan dideteksi dengan menggunakan uji Durbin-Watson. Hasil uji awal ditunjukkan dalam Tabel 5.

Tabel 5. Hasil Uji Durbin-Watson Awal

\begin{tabular}{lr}
\hline Model & Durbin-Watson \\
\hline 1 & 1.512 \\
\hline
\end{tabular}

Sumber: Data sekunder (diolah), tahun 2018

Pada hasil uji autokorelasi awal yang ditunjukkan dalam Tabel 5 dihasilkan nilai angka DW (Durbin-Watson) sebesar 1,512 dengan $d l=1,5723$ dan $d u=1,7199$. Pengambilan keputusan pada autokorelasi di 4 - du $(4-1.7199=2.2801)$, dimana pendeteksian autokorelasi adalah 1,5723 > $1,512<2,2801$. Dengan demikian dinyatakan model mengalami kondisi autokorelasi. Untuk mengatasi persoalan ini, maka dilakukan 'pengobatan' (repaired) pada DW, dimana hasilnya ditunjukkan dalam Tabel 6.

Tabel 6. Hasil Uji Durbin-Watson Repaired

\begin{tabular}{lr}
\hline Model & Durbin-Watson \\
\hline 1 & 1.800 \\
\hline
\end{tabular}

Sumber: Data sekunder (diolah), tahun 2018

Pada hasil uji autokorelasi setelah dilakukannya 'pengobatan' pada DW seperti terlihat dalam Tabel 6, diperoleh angka DW sebesar 1,800 dengan $d l=1,5723$ dan $d u=$ 1,7199. Pengambilan keputusan untuk kondisi autokorelasi di 4 - du $(4-1,7199=2,2801)$, dimana pendeteksian autokorelasi adalah $1,5723<1,800<2,2801$. Dengan demikian setelah dilakukan repaired pada DW, dinyatakan bahwa model tidak mengalami autokorelasi.

\section{Pengujian Hipotesis}

Pengujian hipotesis bertujuan untuk menjawab suatu hipotesis yang diajukan dalam penelitian. Dalam menjawab hipotesis penelitian terdiri dari dua pengujian hipotesis, yaitu pengujian hipotesis parsial (uji $t$ ) dan pengujian hipotesis simultan (uji $F$ ).

\section{Pengujian Hipotesis Parsial}

Pengujian hipotesis parsial bertujuan untuk menguji hipotesis secara individual. Dalam penelitian ini adalah untuk mengetahui derajat signifikansi dari pengaruh SBI, jumlah uang beredar dan ekspor terhadap inflasi yang dilakukan secara individual. Hasil dari uji parsial ditunjukkan dalam Tabel 7.

Hasil uji parsial dalam Tabel 7 selanjutnya diinterpretasikan sebagai berikut.

- Untuk variabel SBI diperoleh nilai t-hitung sebesar 0,721 dan nilai t-tabel sebesar 1,6388. Hasil perbandingan menunjukkan bahwa nilai $t$-hitung $<t$-tabel, sehingga dinyatakan bahwa SBI tidak berpengaruh terhadap inflasi.

- Untuk variabel jumlah uang beredar diperoleh nilai t-hitung sebesar 0,710 dan nilai t-tabel sebesar 1,6388. Hasil perbandingan menunjukkan bahwa nilai t-hitung $<$ t-tabel, sehingga dinyatakan bahwa jumlah uang beredar tidak berpengaruh terhadap inflasi.

- Untuk variabel ekspor diperoleh nilai $t$ hitung sebesar 1,3726 dan nilai t-tabel sebesar 1,6388. Hasil perbandingan menunjukkan bahwa nilai thitung $<$ t-tabel, sehingga dinyatakan bahwa ekspor tidak berpengaruh terhadap inflasi.

Dengan demikian, hipotesis (1), (2) dan (3) yang diajukan dalam penelitian ini dinyatakan ditolak atau tidak dapat dibuktikan kebenarannya. 
Tabel 7. Hasil Uji Hipotesis Parsial

\begin{tabular}{llrr}
\hline Model & & $\mathrm{t}$ & \multicolumn{2}{c}{ Sig. } \\
\hline 1 & (Constant) & -.059 & .953 \\
& SBI & .631 & .530 \\
& Jumlah Uang Beredar & -.238 & .812 \\
& Ekspor & .598 & .551 \\
\hline
\end{tabular}

Sumber: Data sekunder (diolah), tahun 2018.

Tabel 8. Hasil Uji Hipotesis Simultan

\begin{tabular}{llrr}
\hline Model & & F & \multicolumn{2}{c}{ Sig. } \\
\hline 1 & Regression & .793 & $.501^{\mathrm{a}}$ \\
& Residual & & \\
& Total & & \\
\hline
\end{tabular}

Sumber: Data sekunder (diolah), tahun 2018.

\section{Pengujian Hipotesis Simultan}

Pengujian hipotesis simultan bertujuan untuk menguji hipotesis secara serempak atau simultan. Dalam penelitian ini adalah untuk mengetahui derajat signifikansi dari pengaruh SBI, jumlah uang beredar dan ekspor terhadap inflasi yang dilakukan secara simultan. Hasil dari uji parsial ditunjukkan dalam Tabel 8 .

Hasil uji parsial dalam Tabel 8 menunjukkan bahwa nilai $F$-hitung sebesar 0,793 dan $F$-tabel sebesar 2,81. Hasil perbandingan menunjukkan bahwa nilai $F$-hitung $<F$-tabel, sehingga dinyatakan bahwa SBI, jumlah uang beredar dan ekspor tidak memiliki pengaruh terhadap inflasi.

\section{Koefisien Determinasi}

Koefisien determinasi bertujuan untuk dapat mengetahui seberapa besar kemampuan variabel independen $(X)$ dalam menjelaskan variansi yang terjadi pada variabel dependen $(Y)$. Dalam penelitian ini adalah untuk mengetahui kontribusi dari SBI, jumlah uang beredar dan ekspor, dalam menjelaskan variasi yang bisa terjadi pada inflasi. Hasil dari koefisien determinasi ditunjukkan dalam Tabel 9.

Hasil koefisien determinasi dalam Tabel 9 menyatakan nilai Adjusted $R$-Square sebesar $-0,008$ atau $-0,8 \%$. Hasil ini disebabkan hasil pengujian parsial maupun simultan yang menyatakan bahwa tidak ada variabel independen yang memiliki pengaruh terhadap variabel dependen.

Tabel 9. Hasil Koefisien Determinasi

\begin{tabular}{lr}
\hline Model & Adjusted R-Square \\
\hline 1 & -.008 \\
\hline
\end{tabular}

Sumber: Data sekunder (diolah), tahun 2018

\section{Pembahasan}

Hasil penelitian menyatakan bahwa SBI tidak berpengaruh terhadap inflasi. Hasil ini tidak senada yang diungkapkan Krisnaldy (2017), bahwa inflasi di Indonesia dapat dipengaruhi oleh beberapa faktor seperti, jumlah uang beredar. Menurut pendapat kaum moneteris, jumlah uang beredar adalah faktor utama penyebab inflasi. Apalagi persentase peredaran uang kartal lebih kecil daripada persentase jumlah uang giral, sehingga berdampak terhadap semakin sulitnya proses pengendalian jumlah uang beredar, juga semakin meluasnya moneterisasi dalam kegiatan perekonomian.

Faktor lainnya yang mengakibatkan terjadinya inflasi adalah Produk Domestik Bruto (PDB), dimana pendapatan masyarakat berpengaruh terhadap tingkat inflasi. Apabila pendapatan masyarakat turun maka inflasi akan meningkat. Namun hasil yang diperoleh dalam penelitian ini tidak sejalan dengan hasil penelitian yang dilakukan Larasati dan Amri 
(2017), dimana penelitian ini SBI dinyatakan tidak berpengaruh terhadap inflasi. Akan tetapi hasil penelitian ini sesuai dengan Krisnaldy (2017) dimana hasil penelitiannya menyatakan bahwa suku bunga tidak berpengaruh terhadap inflasi.

Hasil berikutnya dalam penelitian ini adalah bahwa jumlah uang beredar tidak berpengaruh terhadap inflasi. Hasil ini tidak sejalan dengan pendapat Krisnaldy (2017) menyatakan bahwa inflasi di Indonesia dapat dipengaruhi oleh beberapa faktor, seperti, jumlah uang beredar. Menurut argumen kaum moneteris, jumlah uang beredar adalah faktor utama penyebab inflasi. Apalagi persentase peredaran uang kartal lebih kecil daripada persentase jumlah uang giral, sehingga berdampak terhadap semakin sulitnya proses pengendalian jumlah uang beredar, juga semakin meluasnya moneterisasi di dalam kegiatan perekonomian. Faktor lainnya yang mengakibatkan terjadinya inflasi adalah Produk Domestik Bruto (PDB), dimana pendapatan masyarakat berpengaruh terhadap tingkat inflasi. Bila pendapatan masyarakat turun maka inflasi akan meningkat. Akan tetapi, hasil penelitian ini sejalan dengan hasil penelitian yang diperoleh Parlambang (2010), bahwa jumlah uang beredar tidak berpengaruh terhadap inflasi.

Hasil keempat yang diperoleh dalam penelitian ini adalah bahwa ekspor tidak berpengaruh terhadap inflasi. Hasil ini tidak sejalan dengan pendapat bahwa ekspor juga dipengaruhi oleh tingkat inflasi. Argumen ini sebagaimana diungkapkan oleh Silviana (2016) bahwa inflasi merupakan proses kenaikan harga-harga umum dari barangbarang secara terus menerus selama periode tertentu, dimana tingkat inflasi melemahkan neraca perdagangan. Hal ini disebabkan karena inflasi akan mendorong pelemahan daya saing dan pada akhirnya menyebabkan penurunan ekspor (Ansahari dkk., 2017).

Terakhir, peneliti menyatakan bahwa inflasi berpengaruh terhadap cadangan devisa, dimana hal ini sejalan dengan pendapat bahwa beberapa faktor yang mempengaruhi cadangan devisa adalah ekspor, impor, nilai tukar rupiah, dan tingkat inflasi. Hubungan ekspor terhadap cadangan devisa adalah dalam melakukan kegiatan ekspor, Melalui kegiatan itu, suatu negara akan memperoleh berupa nilai sejumlah uang dalam valuta asing atau biasa disebut dengan istilah devisa, yang juga merupakan salah satu sumber pemasukan negara. Sehingga apabila tingkat ekspor mengalami penurunan, maka akan diikuti dengan ikut menurunnya cadangan devisa yang dimiliki (Reny \& Agustina, 2014).

\section{KESIMPULAN}

Berdasarkan hasil-hasil penelitian dan pembahasan, maka bisa disimpulkan: (1) SBI terbukti tidak ber-pengaruh terhadap inflasi; (2) jumlah uang beredar tidak berpengaruh terhadap inflasi; (3) ekspor tidak berpengaruh terhadap inflasi; serta, (4) inflasi berpengaruh terhadap cadangan devisa.

\section{DAFTAR PUSTAKA}

Adiyadnya, M.S.P. 2017. Analisis Pengaruh Inflasi, Kurs Dollar Amerika, Suku Bunga Kredit dan Utang Luar Negeri terhadap Cadangan Devisa Indonesia Tahun 1996-2015. Jurnal Riset Akuntansi. Vol. 7, No. 1, hal. 68-78.

Agustina dan Reny. 2014. Pengaruh Ekspor, Impor, Nilai Tukar Rupiah, dan Tingkat Inflasi terhadap Cadangan Devisa Indonesia. Jurnal Wira Ekonomi Mikroskil. Vol. 4, No. 2, hal. 61-70.

Krisnaldy. 2017. Pengaruh Jumlah Uang Beredar, Produk Domestik Bruto, Kurs dan Tingkat Bunga terhadap Inflasi di Indonesia Pendekatan Error Corection Model. Jurnal Kreatif. Vol. 5, No. 1, hal. 132-140.

Larasati, D.M. dan Amri. 2017. Pengaruh Tingkat Suku Bunga Sertifikat Bank Indonesia dan Nilai Tukar Terhadap Inflasi di Indonesia. Jurnal Ilmiah Mahasiswa (JIM). Vol. 4, No. 2, hal. 535-543.

Perlambang, H. Analisis Pengaruh Jumlah Uang Beredar, Suku Bunga SBI, Nilai Tukar terhadap Tingkat Inflasi. Media Ekonomi. Vol. 19, No. 2, hal. 49-67. 
Putra, I.B.P.P. dan Indrajaya, I.G.B. 2013. Pengaruh Tingkat Inflasi, Utang Luar Negeri dan Suku Bunga Kredit terhadap Cadangan Devisa Indonesia
Tahun 1996-2011. Jurnal Ekonomi Pembangunan Universtas Udayana. Vol. 2, No. 11, hal. 533-538. 